\title{
Exploring bilingualism in a monolingual school system: insights from Turkish and native students from Belgian schools
}

Orhan Agirdag*

\author{
Department of Sociology, Ghent University, Korte Meer 5, 9000 Ghent, Belgium
}

(Received 21 September 2009; final version received 13 January 2010)

A growing body of empirical studies indicates the educational benefits of bilingualism. Despite this tendency, bilingual minority students are being pressured by school authorities to shed their mother tongues. We conducted qualitative interviews with Turkish-bilingual and native-monolingual students in Flemish (Belgium) secondary schools to investigate how students evaluate their languages, how Dutch monolingualism is imposed, and how students respond to the dominance of monolingualism. Our results indicate that the mother tongues of bilingual students are mainly perceived as a barrier to educational and occupational success, while the benefits of bilingualism are unknown. Thus, both Turkish-bilingual and native-monolingual students approved of speaking one language. We also found that monolingualism was strongly imposed on students by explicit encouragement, formal punishment when bilinguals speak their mother tongue, and exclusion of foreign languages from the cultural repertoire of the school. These results are discussed as they relate to policy-makers, scholars of bilingualism and institutional racism.

Keywords: bilingualism; monolingualism; Turkish students; doxa; institutional racism; bilingual education

\section{Introduction}

Bilingualism of minority students is an issue that is widely neglected by both Belgian and British sociologists of education. In both the United Kingdom and Belgium, autochthonous languages are supported in education (e.g. Dutch and French in Belgium; English and Welsh in the United Kingdom), while the languages of immigrant and ethnic-minority children (such as Turkish, Punjabi, or Arabic) are largely ignored and the linguistic identities of minority students are unwelcome in their schools. Furthermore, many educational institutions in western countries put increasing socio-political pressure on linguistic minorities to abandon their mother tongues, which parallels the ever growing nationalism (for the United States, see Macedo 2000; for France, see Helot and Young 2002; for Belgium, see Blommaert and Van Avermaet 2008).

In strong contrast, a growing body of empirical studies, mainly from the United States, indicates the educational benefits of bilingualism (Bialystok 1988; Zhou and Bankston 1998; Cummins 2000; Portes and Hao 2002; Lutz and Crist 2009). These studies have repeatedly shown that bilingual students, who are proficient speakers of

*Email: Orhan.Agirdag@UGent.be 
both their home and host language, outperform their monolingual counterparts in academic achievement. However, very few researchers have extensively investigated how the students experience their languages in a monolingual educational context such as in England or Flanders ${ }^{1}$ (for notable exceptions, see Martin and Stuart-Smith 1998; Leman 1997). As a result, even less is known about how bilingualism is evaluated in such contexts, how monolingualism is imposed on students, and how they respond to the dominance of monolingualism.

The main purpose of this study is to determine the opinion of students about their language(s) within the context of a monolingual education system in Flanders. Thus, we interviewed students of secondary schools in Flanders that are bilingual (Turkish immigrants) or monolingual (Flemish natives) to compare their perspectives. The former group was chosen because Turkish minority students are considered underachievers in both Flanders and England and have received little attention from researchers (Stevens 2008; Faas 2008).

This article will describe our study setting as well as briefly review past research on bilingualism and its links to the policies of language assimilation. It will also present a conceptual framework that encompasses Pierre Bourdieu's theory of linguistic domination (1977a, 1977b, 1998). Finally, we will explain our methodology, present our findings, and discuss their implications for educational policy and research.

\section{Study setting}

This study was conducted in Flanders, which rapidly developed into a multicultural society comprised of immigrants from southern Europe, Turkey and North Africa after World War II. Immigration was restricted by the government in 1973, but the influx of immigrants continued via family reunification and matrimonial migration (Lesthaeghe 2000; Sierens 2006). Dutch is the official language of Flanders; however, first-generation and second-generation immigrants often speak additional minority languages such as Turkish and Arabic dialects (Van Craen, Vancluysen, and Ackaert 2007). However, these immigrants are rarely referred to as 'bilingual', but rather as 'linguistically different' (anderstaligen).

To date, second-generation and third-generation immigrants have fewer educational achievements than natives (Lesthaeghe 2000; Sierens 2006). In Flanders, this educational inequality is one of the highest among all countries in the Organisation for Economic Co-Operation and Development (2006) and can be explained by factors such as differences in socio-economic status and track placement. However, the linguistic backgrounds of immigrants are still perceived as the main source of their learning difficulties (Hirtt, Nicaise, and De Zutter 2007).

Even though Belgium has two major languages (i.e. Dutch in Flanders, and French in Wallonia), bilingual instruction does not occur since Belgian law only permits education in one official language (Manco and Crutzen 1999; Agirdag 2009). Bilingual instruction is only allowed at the experimental level and few projects on this subject have been conducted. The most well-known example is the Foyer Project in the capital city of Brussels, which involved bilingual instruction in Dutch combined with Turkish, Italian or Spanish. Although the Foyer Project yielded favourable results in terms of parental involvement and educational achievement, to date no form of bilingual education has been integrated into the regular school system (Leman 1997; Manco and Crutzen 1999). 
In Flanders, the overwhelming social and political pressure for Dutch monolingualism and the aversion to bilingual education may be related to rising nationalism and the strong presence of the far right-wing in Flemish politics. For instance, 'Vlaams Belang' - which is an extremist political party similar to the British National Party - is presently the largest opposition party in Flanders, and, although it is currently not in power, their rising nationalism has considerably affected mainstream policies, which do not include linguistic pluralism (see Blommaert and Van Avermaet 2008). Along these lines, recent policies have excluded non-Dutch speakers from social housing. With respect to educational policy, the former Flemish Minister of Education called linguistic assimilation of immigrant children a top priority of the 'equal opportunities' policy. Furthermore, the present Flemish Minister of Education claimed that the educational inequalities between natives and immigrants are only caused by 'language deficiencies' of immigrant pupils.

\section{Past research and politics of bilingualism}

Flanders is not an exceptional case when it comes to the political pressure toward monolingualism. Here we provide a brief history of language policies, organized into three time periods, and how they relate to scholarship about the impact of bilingualism (for more comprehensive accounts, see Diaz 1983; Baker 1996; Pavlenko 2002; Crawford 2004).

\section{Early assimilation (1920-1960)}

In the first half of the twentieth century, numerous empirical studies claimed that bilingual children suffered from a 'language handicap' and were inferior in intellectual development, indicating that linguistic assimilation was necessary (for reviews, see Diaz 1983; Hakuta and Diaz 1985; Portes and Schauffler 1994; Baker 1996). The political ideology in western countries was analogous to the then dominant scientific knowledge. In the United States, for example, English monolingualism was considered the first step toward a successful integration into society and symbolized ultimate loyalty to the country (Pavlenko 2002). Similarly, the ideology of 'one language, one nation' gained credence in most European countries during this time period and reached its peak before the World War II (Clyne 1997; Hornberger 2002).

\section{Differentialist turn (1960-1990)}

Early studies of bilingualism commonly had methodological flaws in that many of them failed to control for relevant variables such as socio-economic status (Diaz 1983; Hakuta and Diaz 1985). However, Peal and Lambert's (1962) landmark study marked a turning-point in the history of bilingualism research. After appropriately controlling for differences in socio-economic status, age, and sex, they revealed that bilinguals outperform monolinguals in almost all tests of cognitive ability (Peal and Lambert 1962). From then on, and with few exceptions (for example, Gupta 1997), sociolinguistic and sociological studies confirmed that bilingualism positively impacts students' educational performance. These results have been attributed to different factors (for a review and critique, see Mouw and Xie 1999). Once again, parallel developments occurred in the political ideology: throughout the 1960s, a more pluralistic understanding of cultural and linguistic differences gained influence 
and state-sponsored teaching of linguistic minority languages became more prevalent in various western countries. For example, in 1968, the US federal government passed the Bilingual Education Act that legitimized the funding and implementation of bilingual education and the Welsh Language Act of 1967 recognized bilingual instruction through Wales (Garcia 1997).

\section{Return of assimilation (1990-present)}

The debate about bilingualism continued during the second half of the twentieth century. Starting in the 1990s, however, remarkable changes in language policies took place with increasing pressure on immigrants and their children to speak only the host language. For example, three states in the United States (California, Arizona and Massachusetts) passed laws that dismantled or limited bilingual education (Cummins 2000; Macedo 2000; Hurtado and Vega 2004). In 2004, the Netherlands stopped subsidizing almost all forms of bilingual education. Brubaker (2001), who analysed contemporary policies in different western countries, suggested that signs of the 'return of assimilation' could be discerned.

As a consequence, a discrepancy between scholarly research and public policy emerged in that empirical studies argued that bilingualism is related to advantageous academic and socio-emotional outcomes (see Baker 1996; Portes and Hao 2002; Lutz and Crist 2009), while policy-makers considered bilingualism as an obstacle for educational integration. Confronted with this discrepancy, many scholars heavily criticized this contemporary focus on monolingualism (Cummins 2000; SkutnabbKangas 2000; Macedo 2000; Arce 2004).

\section{Bourdieu's theory on linguistic domination}

The above ideas raise the question of how monolingualism and bilingualism is negotiated within a monolingual school system; in our case, secondary schools in Flanders. To be more specific, what are the opinions of monolingual and bilingual students concerning Dutch monolingualism, how is Dutch monolingualism imposed on students and how do they respond to it? To conceptualize these questions, we consider theoretical writings of Pierre Bourdieu (1977a, 1977b, 1998).

\section{Dominant and dominated languages}

In 'The Economics of Linguistic Exchanges', Bourdieu (1977a) states that it would be naive to regard language as a static instrument of communication or even of knowledge. He also indicated that linguistic exchanges or transactions (i.e. language use and the symbolic values given to linguistic practices) are highly dependent on the social contexts in which these 'exchanges' happen. For example, speaking dialect might be accepted, and even appreciated, within the social context of family, while it is unlikely that this will be the case within the context of an academic workplace. Bourdieu called these social contexts 'linguistic fields' and stated that 'all particular linguistic transactions depend on the structure of the linguistic field' (Bourdieu 1977a, 607). A linguistic field primarily involves power relations between the dominant and the dominated groups and between the dominant and dominated languages. Bourdieu asserted that in a situation of bilingualism, a dominant and dominated language will emerge along social class lines: 
A language is worth what those who speak it are worth, i.e. the powers and authority in the economic and cultural power relations ... the dominant language is the language of the dominant class. (Bourdieu 1977a, 652)

From this point of view, it should be clear that, within the Flemish educational system, the languages of social-economically deprived minorities, such as Arabic and Turkish, can be conceptualized as dominated languages, while Dutch can be considered the dominant language.

\section{Doxa, heterodoxy and orthodoxy}

Drawing upon Bourdieu's more general theoretical writings, we can formulate expectations or hypotheses ${ }^{2}$ about the opinions (doxa) and practices (orthodoxy and heterodoxy) of these dominant and dominated groups. First, even if monolingualism, as a form of linguistic domination, clearly favours the dominant group, Bourdieu argues that domination relations can only persist as long as they are commonly perceived as something natural and obvious. In other words, it can be expected that both the dominant and dominated groups share the same opinion in favour of the dominant group. Bourdieu calls such beliefs or opinions the doxa:

Doxa is a particular point of view, the point of view of the dominant, which presents and imposes itself as a universal point of view - the point of view of those who dominate ... and who have constituted their point of view as universal by constituting the State. (Bourdieu 1998, 57)

Applying this framework to our topic, the doxa of monolingualism can be regarded as the point of view of the dominant native-monolingual group that favours (Dutch) monolingualism. Due to power inequalities, however, it can be expected that these opinions in favour of monolingualism will be imposed on the dominated groups, mainly via the school system. As a result, both the dominant and dominated groups can be expected to welcome (Dutch) monolingualism (Bourdieu 1977b, chap. 4). Thus, although the doxa of monolingualism is the point of view of the dominant native-monolingual group, we can expect that the dominated immigrant-bilingual group will also prefer monolingualism.

Secondly, Bourdieu indicated that these same groups may differ in their practices concerning the doxa, despite the apparent 'consensus' when it comes to their opinions. Hence, a discrepancy may occur between what individuals think and what they actually do. Bourdieu (1977b, 1998) stated that dominant groups are more likely to behave in an orthodox manner, meaning they are more likely to impose the doxa. These actions would happen pre-eminently within the school system or the educational 'field'. On the other hand, the dominated groups are more likely to behave heterodox, thus they will 'have an interest in pushing back the limits of doxa' (Bourdieu 1977b, 169). ${ }^{3}$

Considering the linguistic domination theory, the following hypotheses can be formulated: (1) doxa - both the dominant (native-monolinguals) and the dominated (immigrant-bilinguals) groups will favour Dutch monolingualism; (2) orthodoxy - the dominant group will impose Dutch monolingualism through the educational system; and (3) heterodoxy - the dominated group will oppose Dutch monolingualism in their practices. 


\section{Methods}

Our analysis is based on semi-structured, in-depth interviews in which 'the interviewer asks certain, major questions the same way each time, but is free to alter the sequence and to probe for more information' (Fielding 1993, 136). The in-depth approach was necessary to create an informal atmosphere that would allow the respondents to speak at length and build a relationship with the interviewer based on mutual trust, a process that strengthens the reliability of the data. The disadvantage of such an approach is that the sample size is relatively small. Nineteen students, bilinguals and monolinguals, were interviewed. The age range of these students was 14-17 years, with a median age of 15 years. The interviews lasted between one and 2.5 hours (averaging about 1.5 hours).

Our respondents were chosen from five secondary schools, during the 2006/07 school year. They were enrolled in schools in the province of Limburg, which is an area of diverse ethnic communities, particularly the Turkish immigrant community (Van Craen, Vancluysen, and Ackaert 2007). In comparison with natives, most of our Turkish respondents were from a working-class background (as their low parental education indirectly indicates) and were mostly placed in vocational tracks (see Table 1). These characteristics reflect the educational ethnic inequality in Flanders (see above). We measured parental education by the highest degree achieved by either the students' father or mother; parents who graduated from general high school were categorized as highly educated. Students were then grouped according to high and low parental education (see Table 1).

A potential drawback of this study is that only male students were included in the sample. Although we were aware that this selective approach may have implications for the scope of our study, the focus on one gender was a deliberate choice, motivated by methodological and practical reasons. This limitation did not allow investigations of gender differences but enabled controls for gender effects, which were important given the small sample (see Wodak and Benke 1997). We chose male students in order to match the gender of the respondents to that of the interviewer, who was also male. The interviewer proficiently spoke both Turkish and Dutch. While bilingual students were not restricted to speak Turkish during the interview, for the most part the interviews were conducted in Dutch (for a critique of this approach, see Martin and Stuart-Smith 1998). Due to translation to English, some nuances and typical Dutch expressions may be lost in this report. All interviews were audio-taped and transcribed. These transcriptions were analysed using qualitative data software, by detailed reading and successive open and focused coding (Esterberg 2002). The evidence and counterevidence that supported, contradicted or complemented our hypotheses were illustrated by means of quotes from the interviews. In order to assure anonymity, we used pseudonyms instead of real names.

Table 1. Sample according to immigration background, parental education and academic tracking $(n=19)$.

\begin{tabular}{lcccccc}
\hline & \multicolumn{2}{c}{ Low parental education } & & \multicolumn{2}{c}{ High parental education } \\
\cline { 2 - 3 } \cline { 5 - 6 } & General track & Vocational track & & General track & Vocational track \\
\hline Native & 2 & 2 & & 4 & 1 \\
Turkish immigrant & 3 & 4 & & 1 & 2 \\
\hline
\end{tabular}




\section{Findings}

\section{Doxa: opinions about monolingualism}

We first tested Hypothesis 1 - that both the dominant (native-monolinguals) and dominated (immigrant-bilinguals) groups of students will favour Dutch monolingualism. We did not pose explicit questions about linguistic issues so that the answers of our respondents would not influenced. For example, if we had asked them whether they think that proficiency in Dutch is important, they may be inclined to give an affirmative answer. Instead we asked general questions, such as 'What do you think about the lower educational achievement of immigrant students?' or 'How do you feel about immigrants adaptation into the Belgian society?'. Responses will only support our first hypothesis if both groups of respondents, native-monolinguals and immigrantbilinguals, spontaneously mention a positive belief in the primacy of the Dutch language.

First, with just one exception, all of our respondents mentioned the importance and supposed advantages of proficiency in Dutch at least once. Most of the time, this happened when the researcher posed questions about why immigrant students are prevalently underachievers. Consider the responses of Maarten and Bert, both nativemonolinguals:

Language deficits, they have to speak more Dutch. They are not stupid or anything, but they don't speak Dutch well. My classmate M. speaks very well, so he's studying economics. (Maarten)

Often I think that it must be a language problem because when they speak Turkish at home and with their friends, I think it gets trickier to understand difficult words during the lessons like others do. The courses are taught in Dutch and they don't slow it down for them. When they don't understand our language, then they have problems and it is more likely they will switch over to BSO [Dutch abbreviation of vocational track] ... Other than that I think they have equal opportunities as Belgians. It just depends on how much they study and manage their time. But it looks to me that language is very important. (Bert)

Hence, mastering Dutch is considered an asset for immigrant-bilinguals, while the mother tongue is perceived as a barrier to educational success. Moreover, none of the native-monolingual or immigrant-bilingual students spoke of any benefits of being bilingual. Instead, and in line with our first hypothesis, bilinguals as well as monolinguals articulated the favourable aspects of competence in Dutch. For instance, Yilmaz (immigrant-bilingual) testifies:

When you are not a native Dutch speaker, it is kind of difficult. You can't build ... for example [proficiency in] French depends on your Dutch, first you have to completely acquire Dutch and then you can learn other languages, you got it?

Both groups of students unequivocally emphasized the primacy of Dutch monolingualism within the school context. For instance, according to Bram (native-monolingual; see below), linguistic adaptation is the only form of cultural adjustment that may be imposed in the school context, while religious assimilation, for example, cannot be tolerated.

Of course I think it that they should speak Dutch at school. I think they speak Turkish on the playground when they are with their mates. Because of this they may exclude others 
and I don't like it, but that does not often happen in our school. When two or three of them are together, they speak Turkish, but actually the rest of the time they speak Dutch. And I think that they should keep their religion too, because I don't think that one can change that for something like school ... But one must take language into account. (Bram)

When it comes to what immigrant-bilingual students should do at home, however, native students' attitudes towards Dutch monolingualism were more ambiguous. Specifically, we noticed that our respondents did not defend the overall primacy of the Dutch language. This point was demonstrated in our discussions with native-monolingual students Bram and Koen, who stated that it would be 'a good exercise' for immigrants if they spoke Dutch at home, while adding that it should be their choice to do so.

No, at home they might speak Turkish, but for a lot of Turkish people it is a good exercise to talk Dutch at home, then it will become more fluent. But, I think it is their own choice, they have to decide for themselves. If they feel comfortable speaking Turkish at home or to put on a headscarf, nobody should complain about it. (Bram)

At home? I cannot decide about that, neither about school, but one must learn it at home. (Koen)

Immigrant-bilingual students, on the other hand, tend to explicitly reject Dutch monolingualism when it comes to their home lives. Consider, for instance, how Ersan (immigrant-bilingual) responded to our question about what bilinguals should do at home.

That is just... even if they want us to speak Dutch well, they have nothing to say about what we should do at home. If my mother cannot speak Dutch, I can't change that, can I? I cannot do much about it. If I feel ok when I talk Turkish to my parents, do I have to talk Dutch anyway? (Ersan)

To summarize, we found partial support for our first hypothesis. Among students there is indeed a collective belief that Dutch monolingualism is favourable. In addition, immigrant-bilingual and native-monolingual students did not mention any positive effects of being bilingual. It should be noted, however, that support for Dutch monolingualism among immigrant-bilinguals prevailed in the school context but was discredited at home.

\section{Orthodoxy: imposing monolingualism}

Our second hypothesis, which we named orthodoxy, states that Dutch monolingualism is imposed by the dominant groups through the school system. We explored whether such orthodox practices exist and how they take place. Our data indicate that orthodox practices are primarily rooted in the actions of the school staff and teachers, as well as in the cultural policy of the school. Dutch monolingualism is imposed in three general ways. First, we found that teachers and school staff selectively praise or criticize bilingual students' proficiency in Dutch. This rule is conveyed, for instance, by emphasizing the importance of Dutch for their educational and occupation careers.

Actually I do, I want to go to college if I can. My teacher said that I could handle it, but only if I improve my proficiency in Dutch, you know, I make a lot of writing errors and things like that. (Ersan) 
However, none of our respondents mentioned any comment from teachers or schoolmates about the importance of their mother tongues for their educational or occupational careers. In other words, students are only taught the value of their competence in Dutch, while any discourse concerning advantages of bilingualism are absent.

Second, immigrant-bilingual students are not just encouraged to speak Dutch, but they are forced to speak Dutch exclusively, often by means of punishment. Surprisingly, punishing bilingual student for speaking their mother tongue was a common practice. Our respondents from different schools consistently report detention penalties for speaking their home language with peers. For example, Arif and Halit, both immigrant-bilinguals from two distinct schools, commented:

$\begin{array}{ll}\text { Researcher: } & \begin{array}{l}\text { And what does the superintendent do when she sees you speaking } \\ \text { Turkish? }\end{array} \\ \text { Arif: } & \text { Sometimes she says nothing, but most of the time you get a warning. } \\ & \text { After three warnings, you have to stay behind in detention ... Last year I } \\ \text { had to stay behind in detention, this year, not yet. } \\ \text { Researcher: } & \text { And are there some consequences if you speak Turkish? } \\ \text { Halit: } & \text { Yes, if you speak Turkish three times, you get a penalty, at least if you } \\ & \text { get caught [laughs]. But when we are on the playground, with a group of } \\ & \text { five friends and the superintendent sees us, than she knows for sure that } \\ \text { we are speaking Turkish and then she comes in our direction and every- } \\ \text { body instantly starts speaking Dutch. She knows but ... }\end{array}$

Lastly, our data suggest that the home languages of bilingual students are (directly or indirectly) excluded from the school's cultural repertoire, such as assigned books, visits to the cinema, or the available media. This point is powerfully illustrated by Serkan (immigrant-bilingual) while he discussed his media preferences. He stated that he preferred to read Hürriyet, which is a Turkish newspaper that provides news across Europe, but it is impossible to read this paper in his school because checking Turkish web sites is banned. In contrast, reading Het Belang van Limburg, which is a regional Dutch-language newspaper, is permitted.

Serkan: I don't like reading. Sometimes I read a periodical or something and newspapers. In the morning or when I return from school, I often read a Turkish newspaper on the internet.

Researcher: Which newspaper?

Serkan: Hürriyet

Researcher: Do they have Hürriyet in the multimedia centre at your school?

Serkan: $\quad$ No, they don't have Hürriyet. But it is also forbidden to check Turkish websites. I tried once. Each lunch break we go to the multimedia centre and a woman constantly supervises you so you can't go on Turkish websites.

Researcher: And what happens when you read ...

Serkan: Het Belang van Limburg? Yes, that is allowed, but Hürriyet is forbidden. She says: 'I don't understand that'

While it is not clear whether the superintendents and teachers are acting according to a school policy or whether these orthodox actions are based on their own personal beliefs about linguistic diversity, these quotes illustrate, in part, the overwhelming pressure for Dutch monolingualism within the school context. However, it would be wrong to conclude that the cultural repertoire of the school is totally oriented towards Dutch monolingualism because some multilingualism is highly valued. In fact, in almost every school, foreign languages such as English and French are taught and 
students explained that they are required to read books in English (e.g. Animal Farm, Brave New World) or in French (e.g. Le Petit Prince). Hence, in the monolingual school context there is a distinction between 'good' and 'bad' multilingualism; a bilingual student can be punished for not speaking Dutch on the playground, but is then expected to recite Shakespeare in English. Thus, the implicit message conveyed to bilingual students is that mastering different languages is an asset, as long as it is not their mother tongue (for a discussion of 'good' and 'bad' multilingualism, see Van Avermaet 2008).

In sum, in line with our second hypothesis, there is some evidence that Dutch monolingualism is imposed through the school system. Orthodox actions are primarily rooted in the practices of the school staff and teachers. Dutch monolingualism is imposed via three general ways: exclusively communicating the importance of the Dutch language, by penalizing bilingual children when they speak their mother tongue, and by excluding the home language from the cultural repertoire of the school. Our findings suggest that while some multilingualism is valued in the education system, immigrant languages are heavily discouraged.

\section{Heterodoxy: opposing monolingualism}

Our third hypothesis, heterodoxy, states that dominated, immigrant-bilingual students will oppose Dutch monolingualism in their practices. Two examples of bilinguals' heterodox behaviour are tacitly described above: speaking the forbidden mother tongue with their peers, and reading newspapers in their home language at the media centre. However, these heterodox practices are strongly limited in two distinct ways. First, as we described above, bilingual students may be formally punished for speaking their mother tongue. Therefore, heterodoxy is restricted by means of strong orthodoxy. For example, speaking Turkish at the playground is, for Arif (immigrantbilingual), only possible when the superintendent is not present.
Arif:
On the playground, I am usually with Turkish boys, sometimes Belgians, but mostly with Turks.
Researcher: And what language do you talk amongst each other?
Arif: If there is no superintendent around, we speak Turkish.

These orthodox practices might not be sufficient to restrict heterodoxy because external control is not always present; for example, when the superintendent is absent. In addition, we found that heterodoxy is limited by the bilingual students themselves. More specifically, because the bilingual students also approve of Dutch monolingualism, which is the core idea of what we called the doxa of monolingualism, they believe that speaking their mother tongue is 'bad' for them. Therefore, they tend to regret their own heterodox practices. In other words, the doxa of monolingualism partly replaces external control with self-control. This point is illustrated by a quote from our discussion with Ersan (immigrant-bilingual). Ersan told us that he usually speaks Turkish with his peers; he then immediately added that this is 'unfortunate' (see below). He pointed out that teachers are 'quite right' to emphasize the exclusive use of the Dutch language because that is supposed to be useful for their educational and occupational careers.

Researcher: And which language do you speak amongst your friends?

Ersan: Turkish, unfortunately. 
Researcher: Unfortunately?

Ersan: Yes, they want us to speak Dutch.

Researcher: And who wants that?

Ersan: $\quad$ School, generally the administration, everybody. They are quite right to do it. They say when you go to college or work, or apply for a job and so on, they pay attention to your language skills and they say 'you guys have to start speaking Dutch'.

As stated by Cummins (2000), it may be very hard for bilingual children to leave their mother tongue at the school gates. Indeed, our findings suggest that immigrantbilingual students actually take actions against Dutch monolingualism. However, these heterodox practices can hardly be considered a conscious resistance against monolingualism for they are mainly habitual and not related to the knowledge of the favourable effects of bilingualism. Furthermore, potential forms of resistance are profoundly limited by the strong focus on the importance of the Dutch monolingualism. Consequently, bilingual students have few opportunities to oppose Dutch monolingualism. ${ }^{4}$

\section{Discussion and conclusion}

Decades of research have revealed strong evidence indicating that bilingualism is related to favourable outcomes, and several evaluation studies of bilingual education programmes in different countries (such as the United States, Norway, Sweden or Australia) have repeatedly demonstrated that bilingual education is positively related to higher educational achievement and higher socio-emotional well-being (for reviews, see Baker 1996; Krashen 1999). However, there is an increasing sociopolitical pressure on immigrant-bilinguals to renounce their mother tongues in numerous western countries (Cummins 2000; Skutnabb-Kangas 2000). The purpose of our contribution was to gain a clearer understanding of how students themselves think about their languages, to explore how speaking one language is imposed within the monolingual educational system, and how students response to monolingualism. At this point, it should be noted that this study is limited by our small sample size that included male students from two linguistic groups.

First, we found that both groups of students, native-monolinguals and immigrantbilinguals, believe that Dutch monolingualism is advantageous, whereas an awareness of the beneficial outcomes of bilingualism is absent. Second, our data show that Dutch monolingualism is strongly imposed in three different ways: teachers and school staff strongly encourage the exclusive use of Dutch, bilingual students are formally punished for speaking their mother tongue, and their home languages are excluded from the cultural repertoire of the school. At the same time, prestigious languages such as English and French are highly valued. Finally, our findings suggest that some opposition to Dutch monolingualism exists as immigrant-bilingual students try to speak their mother tongue amongst each other. However, the use of those languages at school is strongly limited because bilinguals themselves believe - or are made to believe - that the exclusive use of Dutch produces favourable outcomes. Hence, using home languages is not only discouraged by teachers and school staff, but bilingual students regret their own practices that oppose Dutch monolingualism.

The pressure on linguistic minority students to abandon their mother tongues and the lack of bilingual education are highly related to the literature on institutional racism in education (see Gillborn 2005, 2006, 2008). Institutional racism can be defined as: 'The collective failure of an organisation to provide an appropriate and 
professional service to people because of their colour, culture, or ethnic origin' (Macpherson 1999, 28). In contrast to liberal perspectives that tend to consider 'racism' as an obvious act of discrimination, the literature on institutional racism has pointed out that it includes unwitting (and even well-intentioned) behaviour. Processes of linguistic domination (or monolingualism in education) are related to institutional racism. For instance, the UNESCO Convention Against Discrimination in Education (Article 5) states that linguistic minorities should have the right to use and teach their mother tongues:

It is essential to recognize the right of members of national minorities to carry on their own educational activities, including the maintenance of schools and, depending on the educational policy of each State, the use or the teaching of their own language. (UNESCO $1960,3)$

Hence, depriving linguistic minorities of this right can be considered a 'collective failure' of educational institutions 'to provide an appropriate service'. Secondly, we pointed out that some multilingualism is highly valued, as in almost every school 'white' languages such as English, French and German are welcome. Therefore, it would be naive to assume that 'black' languages such as Turkish or Arabic are coincidently disrespected and it is far more plausible that they are linked to 'the colour, culture, or ethnic origin' of immigrant students. Thirdly, the pressure towards (Dutch) monolingualism is all but an obvious act of discrimination; however, it consists of unwitting and even well-intentioned behaviours. For instance, when school staff argue for the sole use of Dutch or when they punish student for speaking their mother tongue, they are convinced that monolingualism is good for the educational and occupational careers of their students. However, in line with the institutional racism literature, we believe that the effects of racism are more important than its intentions.

On the effects of monolingualism, Baker wrote 'When one or both languages are not functioning fully, because of pressure to replace the home language with the majority language, cognitive functioning and academic performance may be negatively affected' $(1996,148)$, and Cummins stated: 'to reject a child's language in the school is to reject the child' (2001, 19; original emphasis). Therefore, policy-makers, school staff and teachers should avoid pressuring students toward (Dutch) monolingualism and they should consider including languages of minorities in the curriculum and in the cultural repertoire of the school.

In line with the above-cited authors, this paper favours bilingualism and multilingualism in education. However, we argue that advocates of bilingual education should also be cautious. They focus mainly on policy-makers and school administration as they make arguments in support of bilingual education. Often, their underlying assumption is that bilingual students and families will readily welcome such reforms. However, if there is a doxa of (Dutch) monolingualism, and our findings suggest that this is the case, then bilinguals will also believe monolingualism is beneficial and will not oppose it as long as they are unaware of the advantages of their bilingualism. Moreover, bilingual education programmes may fail if bilingual students and families do not understand why their home languages should be prevalent in their education. As a result, projects concerning bilingual education may seem admirable in theory but may fail dramatically in practice. Therefore, in addition to policy-makers and school administrations, supporters of bilingualism should also focus on linguistic awareness of bilingual students and families. 


\section{Acknowledgements}

The author would like to thank two anonymous referees for their constructive comments, particularly on methodological issues and on the relationship between linguistic domination theory and the literature on institutional racism. Special thanks to Mieke Van Houtte, Peter Stevens, Piet Van Avermaet and Simon Boone for their helpful comments on earlier drafts of this article.

\section{Notes}

1. Belgium is a federal country divided into two regions: a Dutch-speaking part in the North (Flanders), and a French-speaking part in the South (Wallonia). These regions are responsible for organizing their educational system.

2. We are aware that the use of hypotheses is more prevalent in quantitative than qualitative research; however, we believe that formulating our theoretical expectations proved promising and helpful in the latter in the current study.

3. The linguistic domination theory of Bourdieu is highly related to the literature on institutional racism in education (see Gillborn 2005, 2006, 2008), and this conceptual relationship is considered in our Discussion.

4. Related to the theme of heterodoxy, there is extensive literature on educational resistance (for the most influential works on this topic, see Willis 1981; Giroux 2001). However, an elaborate discussion of these works is beyond the scope of this paper.

\section{References}

Agirdag, O. 2009. All languages welcomed here. Educational Leadership 66: 20-5.

Arce, J. 2004. Latino bilingual teachers: The struggle to sustain an emancipatory pedagogy in public schools. International Journal of Qualitative Studies in Education 17: 227-46.

Baker, C. 1996. Foundations of bilingual education and bilingualism. Bilingual education and bilingualism 1. 2nd ed. Clevedon: Multilingual Matters.

Bialystok, E. 1988. Levels of bilingualism and levels of linguistic awareness. Developmental Psychology 24: 560-7.

Blommaert, J., and P. Van Avermaet. 2008. Taal, onderwijs en de samenleving. De kloof tussen beleid en realiteit [Language, education and the society. The gap between policy and reality]. Berchem: Epo.

Bourdieu, P. 1977a. The economics of linguistic exchanges. Social Science Information 16: 645-68.

Bourdieu, P. 1977b. Outline of a theory of practice. Cambridge: Cambridge University Press.

Bourdieu, P. 1998. Practical reason: On the theory of action. Stanford, CA: Stanford University Press.

Brubaker, R. 2001. The return of assimilation? Changing perspectives on immigration and its sequels in France, Germany, and the United States. Ethnic and Racial Studies 24: 531-48.

Clyne, M. 1997. Multilingualism. In The handbook of sociolinguistics, ed. C. Florian, 301-14. Oxford: Blackwell.

Crawford, J. 2004. Educating english learners: Language diversity in the classroom. 5th ed. Los Angeles, CA: Bilingual Educational Services.

Cummins, J. 2000. Language, power, and pedagogy: Bilingual children in the crossfire. Bilingual education and bilingualism 23. Clevedon: Multilingual Matters.

Cummins, J. 2001. Bilingual children's mother tongue: Why is it important for education? Sprogforum 19: 15-20.

Diaz, R.M. 1983. Thought and two languages: The impact of bilingualism on cognitive development. Review of Educational Research 10: 23-54.

Esterberg, K.G. 2002. Qualitative methods in social research. Boston: McGraw-Hill.

Faas, D. 2008. Constructing identities: The ethno-national and nationalistic identities of white and Turkish students in two English secondary schools. British Journal of Sociology of Education 29: 37-48.

Fielding, N. 1993. Qualitative interviewing. In Researching social life, ed. G.N. Gilbert, 130-45. London: Sage. 
Garcia, O. 1997. Bilingual education. In The handbook of sociolinguistics, ed. C. Florian, 405-20. Oxford: Blackwell.

Gillborn, D. 2005. Education policy as an act of white supremacy: Whiteness, critical race theory and education reform. Journal of Education Policy 20, no. 4: 485-505.

Gillborn, D. 2006. Citizenship education as placebo: 'Standards', institutional racism and education policy. Education, Citzenship and Social Justice 1, no. 1: 83-104.

Gillborn, D. 2008. Racism and education: Coincidence or conspiracy? New York: Routledge.

Giroux, H.A. 2001. Theory and resistance in education: Towards a pedagogy for the opposition. Westport, CT: Bergin \& Garvey.

Gupta, A.F. 1997. When mother-tongue education is not preferred. Journal of Multilingual and Multicultural Development 18: 496-507.

Hakuta, K., and R.M. Diaz. 1985. The relationship between degree of bilingualism and cognitive ability: A critical discussion and some new longitudinal data. Children's Language 5: $319-44$.

Helot, C., and A. Young. 2002. Bilingualism and language education in French primary schools: Why and how should migrant languages be valued? International Journal of Bilingual Education and Bilingualism 5: 96-112.

Hirtt, N., I. Nicaise, and D. De Zutter. 2007. De school van de ongelijkheid [The school of inequality]. Berchem: Epo.

Hornberger, H.N. 2002. Multilingual language policies and the continua of biliteracy: An ecological approach. Language Policy 1: 27-51.

Hurtado, A., and A.L. Vega. 2004. Shift happens: Spanish and English transmission between parents and their children. Journal of Social Issues 60: 137-55.

Krashen, S. 1999. Condemned without a trial: Bogus arguments against bilingual education. Portsmouth: Heinemann.

Leman, J. 1997. School as a socialising and corrective force in inter-ethnic urban relations. Journal of Multilingual and Multicultural Development 18: 125-34.

Lesthaeghe, R. 2000. Transnational Islamic communities in a multilingual secular society. In Communities and generations: Turkish and Moroccan populations in Belgium, ed. R. Lesthaeghe, 1-57. Brussels: Vub Press.

Lutz, A., and S. Crist. 2009. Why do bilingual boys get better grades in English-only America? The impacts of gender, language and family interaction on academic achievement of Latino/a children of immigrants. Ethnic and Racial Studies 32: 346-68.

Macedo, D. 2000. The colonialism of the English only movement. Educational Researcher 29: $15-24$.

Macpherson, W. 1999. The Stephen Lawrence inquiry. London: Stationery Office.

Manco, A.A., and D. Crutzen. 1999. De moedertaal en de taal waarin onderwezen wordt: Een sociolinguïstische probleem, bestudeerd aan de hand van de situatie van de turken en de marokkanen in belgië [The mother tongue and the language of instruction: A sociolinguistic problem, a study about Turks and Moroccans in Belgium]. In Moedertaalonderwijs bij allochtonen. Geïntegreerd onderwijs in de eigen taal en cultuur [Education in mother tongue for immigrants. Integrated education in own language and culture], ed. J. Leman, 160. Leuven: Acco.

Martin, D., and J. Stuart-Smith. 1998. Exploring bilingual children's perceptions of being bilingual and biliterate: Implications for educational provision. British Journal of Sociology of Education 19: 237-54.

Mouw, T., and Y. Xie. 1999. Bilingualism and the academic achievement of first- and secondgeneration Asian Americans: Accommodation with or without assimilation? American Sociological Review 64: 232-52.

Organisation for Economic Co-Operation and Development. 2006. Where immigrant students succeed. A comparative review of performance and engagement in Pisa 2003. Paris: OECD.

Pavlenko, A. 2002. 'We have room for but one language here': Language and national identity in the US at the turn of the 20th century. Multilingua 21: 163-96.

Peal, E., and W.E. Lambert. 1962. The relation of bilingualism to intelligence. Psychological monographs: General and applied. Washington, DC: American Psychological Association.

Portes, A., and L. Hao. 2002. The price of uniformity: Language, family and personality adjustment in the immigrant second generation. Ethnic and Racial Studies 25: 889-912. 
Portes, A., and R. Schauffler. 1994. Language and the 2nd generation: Bilingualism yesterday and today. International Migration Review 28: 640-61.

Sierens, S. 2006. Immigratiesamenleving, onderwijs en overheid in vlaanderen: Een gespannen driehoeksverhouding [Migration society, education and government in Flanders: A tense triangle]. In Onderwijs onderweg in de immigratiesamenleving [Education on the way in the immigration society], ed. S. Sierens, M. Van Houtte, P. Loobuyck, K. Delrue, and K. Pelleriaux, 9-32. Gent: Academia Press.

Skutnabb-Kangas, T. 2000. Linguistic genocide in education, or worldwide diversity and human rights? Mahwah, NJ: Lawrence Erlbaum Associates.

Stevens, P.A.J. 2008. Exploring pupils' perceptions of teacher racism in their context: A case study of Turkish and Belgian vocational education pupils in a Belgian school. British Journal of Sociology of Education 29: 175-87.

UNESCO. 1960. Convention against discrimination in education, adopted by the General Conference of UNESCO at its eleventh session on 14 December 1960. Paris: UNESCO Publishing.

Van Avermaet, P. 2008. Multilingual spaces in Europe and the use of the CEFR. In Un mondo di italiono, ed. A. Ciliberti, 49-60. Perugia: Guerra Edizioni.

Van Craen, M., K. Vancluysen, and J. Ackaert. 2007. Voorbij wij en zij? De sociaal-culturele afstand tussen autochtonen en allochtonen tegen de meetlat [Beyond us and them? Socialcultural distance between natives and immigrants measured]. Brugge: Vandenbroele.

Willis, P.E. 1981. Learning to labor: How working class kids get working class jobs. Morningside ed. New York: Columbia University Press.

Wodak, R., and G. Benke. 1997. Gender as a sociolinguistic variable: New perspectives on variation studies. In The handbook of sociolinguistics, ed. F. Coulmas, 108-27. Oxford: Blackwell.

Zhou, M., and C.L. Bankston. 1998. Growing up in America: How Vietnamese children adapt to life in the United States. New York: Russell Sage Foundation. 